\title{
Effects of depth and light on secondary metabolites and cyanobacterial symbionts of the sponge Dysidea granulosa
}

\author{
Mikel A. Becerro ${ }^{1,2, *}$, Valerie J. Paul ${ }^{1,3}$ \\ ${ }^{1}$ University of Guam Marine Laboratory, Mangilao, Guam 96923, USA \\ ${ }^{2}$ Present address: Center for Advanced Studies (CEAB, CSIC), 17300 Blanes (Girona), Spain \\ ${ }^{3}$ Present address: Smithsonian Marine Station at Fort Pierce, Fort Pierce, Florida 34949, USA
}

\begin{abstract}
The tropical sponge Dysidea granulosa contains a number of symbiotic heterotrophic bacteria and large quantities of the photosynthetic cyanobacterium Oscillatoria spongeliae, which are reported to be responsible for the production of ecologically active polybrominated diphenyl ethers (BDEs) in Dysidea spp. In order to better understand the relationship between these symbionts and the production of BDEs, we looked at the variation in secondary chemistry in 3 populations of $D$. granulosa and the relationship between cyanobacteria and secondary chemistry in the sponge, and experimentally assessed the role that depth and light play in this relationship by transplanting sponges in the field. At a population scale, the concentration of BDEs is positively correlated with the concentration of chlorophyll $a(\mathrm{chl} a)$, both varying significantly between populations. Yet, in sponges experimentally transplanted to a deeper site, the concentration of chl a decreased significantly while BDE concentration remained stable. We specifically tested the importance of light in determining levels of symbionts and BDEs by placing sponges under transparent, UV-opaque, and black Plexiglas plates. After 5 wk, levels of BDEs and chl a had decreased significantly, although these trends differed between light treatment, suggesting a lack of direct correlation between BDEs and cyanobacterial populations. This was also supported by a within-sponge analysis of chl $a$ and BDEs, since high levels of compounds were found in the choanosome of the sponge, whereas chl $a$ and cyanobacterial contents were minimal. Our data suggest that the relationship between the levels of BDEs in D. granulosa and its photosynthetic symbionts is more complex than expected. Variation in the levels of secondary metabolites and symbionts seems to be related at a population scale, but unrelated at an individual scale.
\end{abstract}

KEY WORDS: Chemistry variation - Depth $\cdot$ Dysidea granulosa Light $\cdot$ Oscillatoria spongeliae Polybrominated diphenyl ethers $\cdot$ Secondary metabolites $\cdot$ Symbionts

\section{INTRODUCTION}

Numerous organisms across broad phylogenetic groups produce secondary metabolites (Faulkner 2001 and previous references in this series). These compounds play a role in important biological processes including reproduction, competition and protection against predators (Coll et al. 1990, Paul 1992, Hay 1996, McClintock \& Baker 2001, Paul \& Puglisi 2004). Rather than constant levels of secondary metabolites, producers have highly variable levels of compounds in their tissues and there is evidence that chemical variation has an effect on predators, competitors, community structure and dynamics, and on evolution (Coley \& Barone 1996, Cimino \& Ghiselin 2001, Paul et al. 2001). Understanding the causes of this variation provides valuable information not only about the factors affecting the production of secondary metabolites but also about the circumstances under which producers invest more in chemical defenses (Karban \& Baldwin 1997).

Light quality and intensity, mineral deficiencies, water availability, temperature, physiological stage, 
genetics, stress, predators, pathogens and competitors are some of the factors that regulate the production of secondary metabolites in terrestrial systems (Rice 1984, Karban \& Baldwin 1997, Wink 1999). In marine systems, most studies have investigated the role of biological factors in the production of secondary metabolites and point to predation as one of the main factors affecting chemical variation (Hay 1996). However, many organisms have a background level of secondary metabolites that is modified by predation. This background level may be determined by genetic as well as physical, biological and environmental factors that have remained largely uninvestigated.

There is some evidence that physical and environmental factors influence the production of secondary metabolites by marine organisms. Desiccation of the brown alga Dictyota ciliolata reduces levels of secondary metabolites and causes the plant to become more susceptible to grazing (Cronin \& Hay 1996a). Nutrient availability determines phenolic levels in Fucus vesiculosus (Yates \& Peckol 1993). Light may also be a factor regulating levels of secondary chemistry in marine organisms. Some compounds are suggested to provide protection against UV radiation in several phyla (Stochaj et al. 1994, Dunlap \& Schick 1998, Karentz 2001), and their levels could be modified according to the amount of UV radiation encountered in the environment (Gleason 1993, Karentz 2001). Moreover, there is evidence that secondary metabolites may be produced by symbionts or associated microorganisms, whose populations could be determined by light and nutrient levels in the environment. Photosynthetic cyanobacteria are responsible for the production of several compounds in Dysidea herbacea (Unson \& Faulkner 1993, Unson et al. 1994). Okadaic acid, found in the sponge Haliclona okadai (Tachibana et al. 1981), is produced by a dinoflagellate (Yasumoto et al. 1987). Antimicrobial compounds from the sponge Hyatella sp. are actually produced by an associated Vibrio sp. (Oclarit et al. 1994), and 2 different classes of compounds from the sponge Theonella swinhoei are produced by 2 different bacterial symbionts present in the sponge (Bewley et al. 1996).

Sponges are widespread organisms that produce a great variety of secondary metabolites (Faulkner 2001) and host large numbers of associated microorganisms in their bodies (Wilkinson 1978, Rützler 1990). These characteristics make sponges excellent organisms in which to study variation in the production of secondary metabolites and the relationship between environmental factors and symbionts. Sponges of the genus Dysidea produce a high diversity of secondary metabolites including terpenes, sterols, chlorinated amino acids, alkaloids and polybrominated diphenyl ethers (Dunlop et al. 1982, Carmeli et al. 1988, Fu \& Schmitz
1996, Bandaranayake et al. 1997, Cameron et al. 2000, Stapleton et al. 2001; see Venkateswarlu et al. 1998 for a review of the extensive literature on secondary metabolites isolated from Dysidea spp.). The secondary chemistry of the tropical species $D$. herbacea has been extensively investigated. In this species, terpene metabolites are localized in sponge cells (Flowers et al. 1998), while polychlorinated alkaloids and brominated diphenyl ethers (BDEs) are associated with the symbiotic cyanobacterium Oscillatoria spongeliae (Unson \& Faulkner 1993, Unson et al. 1994), which implicitly suggests cyanobacteria to be the producers of these compounds. Yet, a marine bacterium isolated from the tropical species Dysidea sp. and cultured on medium broth can biosynthesize BDEs (Elyakov et al. 1991, Voinov et al. 1991).

On the reefs of Guam, the 3 closely related Dysidea species Dysidea n. sp. aff. herbacea (ridged form), Dysidea n. sp. aff. herbacea (smooth form), and Dysidea n. sp. aff. granulosa share habitat and contain photosynthetic cyanobacteria similar to Oscillatoria spongeliae (Kelly et al. 2003, Thacker \& Starnes 2003). Dysidea n. sp. aff. granulosa is morphologically the most dissimilar of the 3 species because, rather than the thinly encrusting sheet-like growth form of the Dysidea n. sp. aff. herbacea species, it has a more massive finger-like appearance and is up to several centimeters in height. There are also internal differences between these species. Dysidea n. sp. aff. granulosa has a large bacterial population distributed throughout its tissue, and a population of genetically distinct cyanobacteria (Thacker \& Starnes 2003) that are exclusively restricted to the outermost 1 to $2 \mathrm{~mm}$ of the sponge surface. In contrast, Dysidea n. sp. aff. herbacea contain a small population of heterotrophic bacteria and abundant cyanobacteria distributed throughout their tissues (Unson et al. 1994). In this study, we selected Dysidea n. sp. aff. granulosa because only this species contains exclusively large amounts of BDEs and abundant bacteria and cyanobacteria as associated microorganisms. Our working hypothesis was that depth and light are factors that directly control levels of polybrominated diphenyl ethers in Dysidea n. sp. aff. granulosa by regulating its cyanobacterial populations, which have been reported to be responsible for the production of these compounds (Unson et al. 1994). We assessed chemical variation and chl a levels in sponges from different locations. Then we tested the importance of depth and light in the production of polybrominated diphenyl ethers and in the levels of chl $a$ in the sponge. We also performed a within-sponge analysis of secondary metabolites and microorganisms associated with the sponge that provides a key to understanding the unexpected results obtained in this study. 


\section{MATERIALS AND METHODS}

Species and study sites. Off the shores of Guam $\left(13^{\circ} 25^{\prime} \mathrm{N}, 144^{\circ} 55^{\prime} \mathrm{E}\right)$, Dysidea n. sp. aff. granulosa (family Dysideidae, order Dictyoceratida) (Kelly et al. 2003, Dysidea sp. 4, hereafter Dysidea granulosa) is a common shallow-water sponge found mostly on reef flats, where it can be locally abundant. Morphologically, it has several finger-like lobes spreading out on the substrate in several directions and can attain an area of up to $400 \mathrm{~cm}^{2}$ and a thickness of about $2 \mathrm{~cm}$ (height) at our study sites. The sponge surface is gray while the sponge inner part is off-white. A voucher of the sponge is deposited in the British Museum of Natural History (BMNH 1995.6.22.7, photo voucher at www.flmnh.ufl.edu/reefs/guam/ guamimg/porifera/Pages/Image36.html). At Guam, this sponge supports large populations of an endosymbiotic filamentous cyanobacterium identified as Oscillatoria spongeliae (Thacker \& Starnes 2003, M. Borowitzka pers. comm.) as well as heterotrophic bacteria. The individual cyanobacterial cells measure about 6 to $10 \mu \mathrm{m}$ wide and about $10 \mu \mathrm{m}$ long, and they form filaments of varying lengths, often exceeding 10 individual cells in our samples. The sponge also contains a number of heterotrophic bacteria varying in shape, size, content and membrane characteristics. Both cyanobacteria and heterotrophic bacteria occur extracellularly in the sponge mesohyl (matrix) (Fig. 1).
Fig. 1. Dysidea granulosa. Histological sections of ectosome and choanosome under light (LM) and electron (TEM) microscopy. LM pictures are all at same magnification and show general aspect of both ectosome and choanosome with sponge cells (diamond arrows), bacteria (normal arrows), cyanobacteria (cb), fibers (fb) and choanocyte chambers (cc). TEM pictures (insets) show presence of various bacterial types in ectosome and choanosome

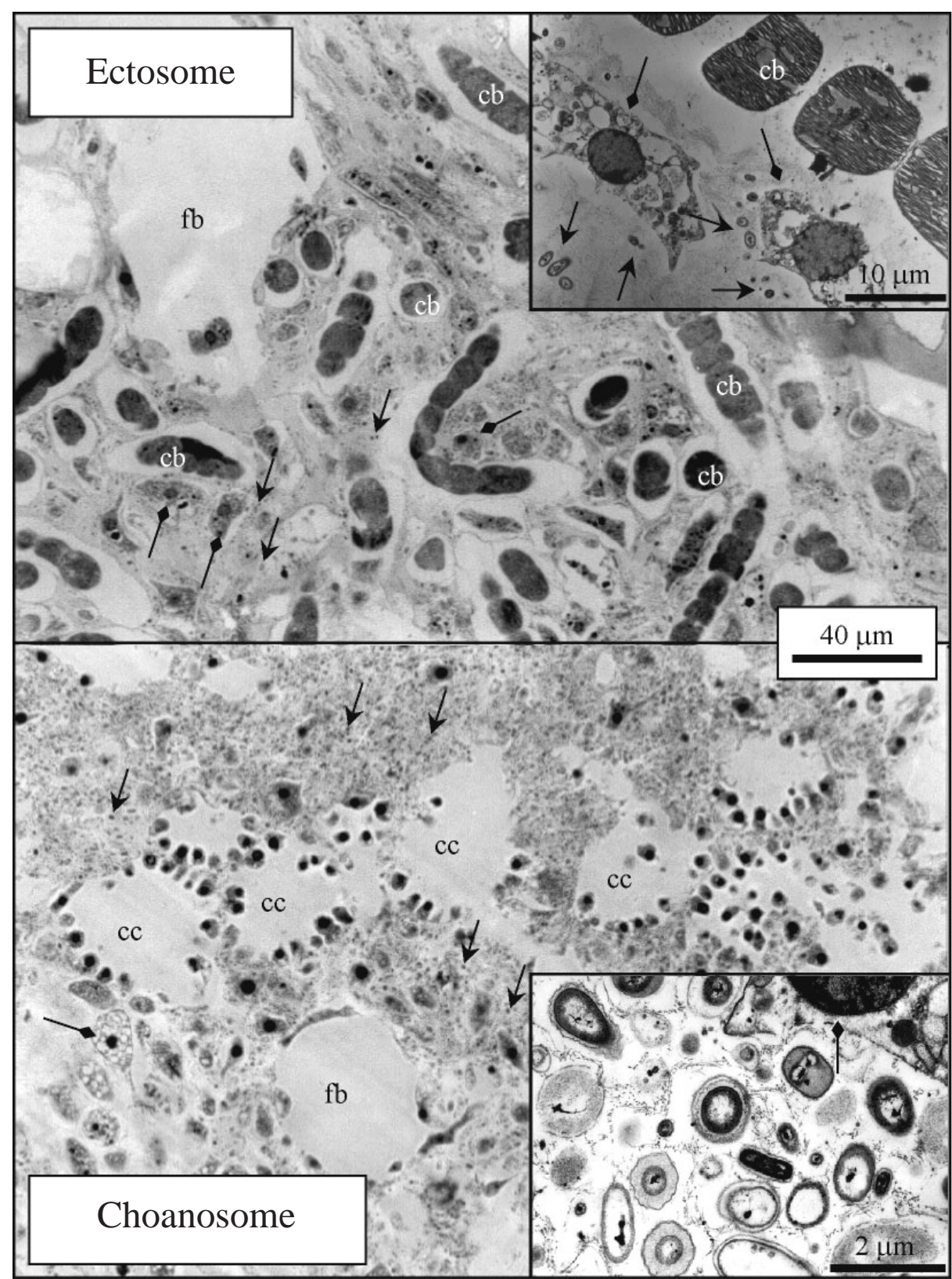


Dysidea granulosa was collected at 3 locations on Guam's fringing reefs. Piti Bombholes reef (hereafter 'Piti') is a large reef flat area protected by a reef edge from surge and wave action. It has a maximum depth of about $2 \mathrm{~m}$ at high tide and a number of 'bombholes' scattered all over the reef flat. These are submerged sinkholes, over $10 \mathrm{~m}$ wide, with a maximum depth about $8 \mathrm{~m}$ at high tide. Piti generally lacks wave action and strong surge but tidal currents are common and can be moderately strong. D. granulosa is present on the reef flat but absent from the slopes and bottom of the bombholes. Gun Beach reef (hereafter Gun) is a reef slope habitat with a series of 1 to $5 \mathrm{~m}$ wide channels whose vertical walls are perpendicular to the shoreline. Depth is about 1 to $2 \mathrm{~m}$ deep at the top of the channels and drops to 5 to $6 \mathrm{~m}$ at the bottom of the channels. Channels are interconnected by small crevices and holes. In contrast to Piti, the reef at Gun is open to wave action and surge, which can be very strong. D. granulosa is found on the channel walls up to a depth of 5 to $6 \mathrm{~m}$. Anae Island (hereafter Anae) is located about half a mile off Guam's coast. The reef surrounding Anae shares characteristics with the reefs at Piti and Gun. It has a number of holes that are smaller in diameter than those at Piti and can be as deep as $\sim 11 \mathrm{~m}$. As at Gun, wave action and surge can be strong. $D$. granulosa inhabits the reef flat areas at Anae up to a depth of about 5 to $6 \mathrm{~m}$.

Secondary metabolites: extraction, isolation and quantification procedures. Several sponges were collected from the 3 locations for general secondary metabolic identification and compound isolation. Sponges were frozen $\left(-20^{\circ} \mathrm{C}\right)$, freeze-dried, ground and extracted with dichloromethane (DCM) $\left(100 \mathrm{ml} \mathrm{g}^{-1}\right.$ dry mass). After $3 \mathrm{~h}$, the extract was filtered out and the sponge material re-extracted with the same amount of DCM. After $3 \mathrm{~h}$, the new extract was filtered out and more DCM was added for an overnight third extraction of the sponge material. This protocol of consecutive extractions allowed a thorough extraction of the secondary metabolites in the samples, as revealed by thinlayer chromatography (TLC) of the sequential extracts. The 3 extracts were pooled, filtered, dried in a rotary evaporator and weighed. This crude extract was then redissolved in DCM and filtered through a small silica column (ethyl acetate:hexanes 20:80) to remove most polar materials. TLC of both crude and filtered extracts showed the presence of 3 major metabolites in the extracts. We used high-performance liquid chromatography (HPLC column: Alltech Econosil 10, $250 \times$ $10 \mathrm{~mm}$, eluant: 20:80 ethyl acetate:hexanes, refractive index detection) to further partition the filtered extract and isolate the 3 major compounds detected by TLC. The structures of the purified Compounds 1 (1,5-dibromo-3-[2', 4 '-dibromo-phenoxy]-2-methoxy- benzene), 2 (3,5-dibromo-2-[2', 4'-dibromo-phenoxy]phenol; Carte \& Faulkner 1981) and 3 (2,4 dibromo-6[2', 4'-dibromo-phenoxy]-phenol; Sharma et al. 1969, Carte \& Faulkner 1981) (Fig. 2) were determined by ${ }^{1} \mathrm{H}$ - and ${ }^{13} \mathrm{C}$-nuclear magnetic resonance spectroscopy (NMR) and mass spectrometry (MS). The purified secondary metabolites were then used to set up a method for their quantification in a gas chromatograph/mass spectrometry system (GC-MS: see below).

All the specimens of Dysidea granulosa studied were individually collected by snorkeling or SCUBA diving, and were taken to the laboratory for quantification of secondary metabolites. Once in the laboratory, all the samples were frozen $\left(-20^{\circ} \mathrm{C}\right)$ after removing any foreign debris (algae, coral rubble, small invertebrates) from the sponge tissues. The frozen samples were then freeze-dried and ground to obtain a homogeneous dry powder per sample. About $500 \mathrm{mg}$ of sponge dry mass per sample (i.e. $500 \mathrm{mg}$ of the dry powder) was extracted with DCM for about $3 \mathrm{~h}$ (1 ml DCM $50 \mathrm{mg}^{-1}$ sponge dry mass). This procedure was repeated twice more to ensure exhaustive extraction. The 3 extracts were pooled, filtered, dried in a rotary evaporator and weighed. The percent yield of crude extract was calculated as mass of extract divided by mass of dry sponge. For the quantification of Compounds 1, 2 and 3 by GC-MS, crude extracts were dissolved $\left(2 \mathrm{ml} \mathrm{mg}^{-1}\right)$ in DCM containing naphthalene $\left(50 \mu \mathrm{g} \mathrm{ml}^{-1}\right)$ as internal standard (IS).

Quantification was done by a Hewlett Packard 5890 Series II GC fitted with an HP-5 capillary column (5\% phenyl methyl cross-linked silicon siloxane, $30 \mathrm{~m}$ long, $0.25 \mathrm{~mm}$ inner diameter, $0.25 \mu \mathrm{m}$ film thickness) and coupled to a Hewlett Packard 5972 mass spectrometer. Gas chromatography was performed in the scan mode using $8.8 \mathrm{psi}$ of helium at $36.6 \mathrm{~cm} \mathrm{~s}^{-1}$ linear velocity. The oven was temperature-programmed for $1.50 \mathrm{~min}$ at $100^{\circ} \mathrm{C}$ and then ramped at $70^{\circ} \mathrm{C} \mathrm{min}^{-1}$ to $290^{\circ} \mathrm{C}$ for $5 \mathrm{~min}$. Injection was made in the splitless mode with an injector-port temperature of $250^{\circ} \mathrm{C}$. MS range was 50 to $600 \mathrm{~m} / \mathrm{z}$ (specific mass/charge). Under these conditions retention times ( $\mathrm{R}$, in $\mathrm{min}$ ) for the IS and the<smiles>Oc1cc(Br)cc(Br)c1Oc1ccc(Br)cc1Br</smiles>

Compound 2<smiles>[R]Oc1c(Br)cc(Br)cc1Oc1ccc(Br)cc1Br</smiles>
Compound 3, $\mathrm{R}=\mathrm{H}$
Compound $1, \mathrm{R}=\mathrm{Me}$

Fig. 2. Dysidea granulosa. Structure of 3 major polybrominated diphenyl ethers present in sponge. Compound 1: 1,5-dibromo-3-(2' '4'-dibromo-phenoxy)-2-methoxy-benzene; Compound 2: 3,5-dibromo-2-(2', 4'-dibromo-phenoxy)-phenol; Compound 3: 2, 4 dibromo-6-(2', 4 '-dibromo-phenoxy)-phenol 
3 polybrominated secondary metabolites are: IS, R $t=$ 3.30; Compound 1, Rt = 7.56; Compound 2, $\mathrm{R} t=7.75$; Compound 3, $\mathrm{R} t=7.98$. Samples were analyzed by injecting $1 \mu \mathrm{l}$ of extract solution at a concentration of $0.5 \mathrm{mg} \mathrm{ml}^{-1}$. We quantified the percent yield of compounds in the extracts by comparing the ratio 'area of compound divided by area of IS' in the samples to a calibration curve calculated with known concentrations of pure compounds (Compound 1, $\mathrm{R}^{2}=0.993$; Compound 2, $\mathrm{R}^{2}=0.989$; Compound 3, $\mathrm{R}^{2}=0.992$ ). To calculate the percent yield of compounds per sponge dry mass we multiplied the proportion yield of compound in the extract by the proportion yield of crude extract in the sponge $\times 100$.

Sampling and experimental design. In this study, we investigated variation in the secondary metabolites of Dysidea granulosa and its symbionts at the population and individual level. We used both observational and experimental approaches to investigate the relationship between secondary metabolites and symbionts and the role that depth and light have in this relationship.

First, we quantified the levels of secondary metabolites and chl $a$ in sponges from Anae, Gun and Piti reefs. We separately analyzed tissues from the ectosome and choanosome of the sponge to investigate within-sponge variation. Ectosome refers to the outer, colored layer of sponge while choanosome refers to the white inner matrix. Ectosome was easily separated from the choanosome by scratching the surface of freeze-dried specimens with a razor-blade until the whitish choanosome was visible. We also investigated withincolony variation by examining branch-tobranch variation in secondary metabolites. A branch refers to each of the finger-like lobes characteristic of Dysidea granulosa. We collected 3 branches from each of 8 sponges from Piti. The data were analyzed by a nested Analysis of Variance with factor branch nested within each level of the factor sponge.

Second, we used an experimental approach to test the importance of depth and light as factors affecting the levels of secondary metabolites in the sponge. To test the importance of depth, we worked with 30 specimens on the reef flat at Piti, transplanted some of these, and quantified the levels of secondary metabolites over a $6 \mathrm{wk}$ period. We labeled 10 specimens, and left them on the reef flat without any handling as an overall control. The remaining 20 specimens were transported to the bottom of the bombholes where 10 specimens were labeled and left at $6 \mathrm{~m}$ as a depth treatment, while the remaining 10 specimens were labeled and transported back to the reef flat as a transplant control (back-transplant).
A small piece of each specimen was collected at the beginning of the experiment (time $=0$ ), after $3 \mathrm{wk}$ (time $=3$ ), and after 6 wk (time =6). Thus, the 10 controls, the 10 back transplants, and the 10 bombhole transplants were repeatedly collected over time and extracted as detailed previously. We quantified levels of Compounds 1, 2 and 3 and chl a (see next subsection for chl a quantification procedure). We analyzed the data with a 2-way repeated measures analysis of variance (ANOVAR) with Time as the within-subject factor and Treatment (control, transplant control and depth treatment) as the between-subject factor.

To test the importance of light on the levels of secondary compounds in Dysidea granulosa, we collected 50 specimens from Piti. Of these 50 specimens, 10 were haphazardly selected, labeled and left on the reef as an overall control (Piti control). The 40 remaining specimens were placed in coolers with seawater and immediately transported $20 \mathrm{~km}$ south to Cocos Lagoon (about 30 min from Piti) where we set up the following experiment (see Fig. 3). We labeled and left 10 speciments on the reef as a transplant control (Cocos transplant control). Another 10 specimens were labeled and placed underneath transparent plates (plate transplant control; PlexiglasII UVT, which allowed passage of all ultraviolet radiation transmitted above $275 \mathrm{~nm}$ and the visible light spectrum), 10 specimens were placed under UV-opaque plates (UV treatment transplant; PlexiglasUF-3 that blocked out light and short-wavelength light transmitted below $450 \mathrm{~nm}$, but allowed passage of the visible light spectrum), and the remain-

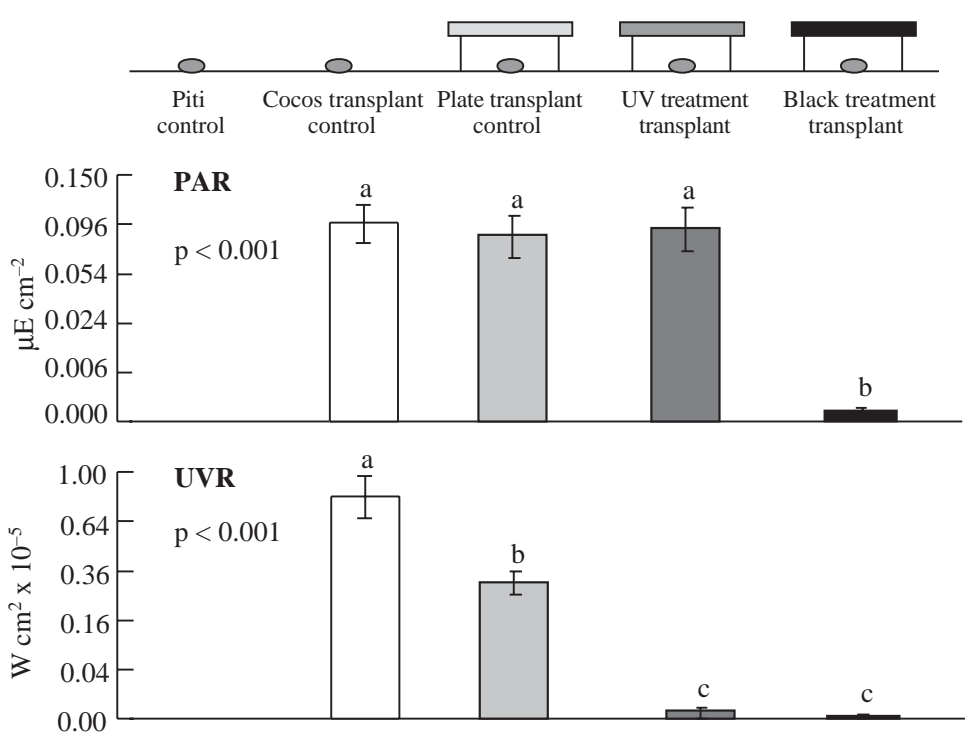

Fig. 3. Mean $( \pm 1 \mathrm{SE}, \mathrm{N}=5)$ photosynthetically active radiation $(\mathrm{PAR})$ and ultraviolet radiation (UVR) received by different treatments in experiment testing effect of light on production of secondary metabolites in Dysidea granulosa. Probabilities calculated by 1-way ANOVA. Bars sharing same letters do not differ at $\alpha=0.05$ 


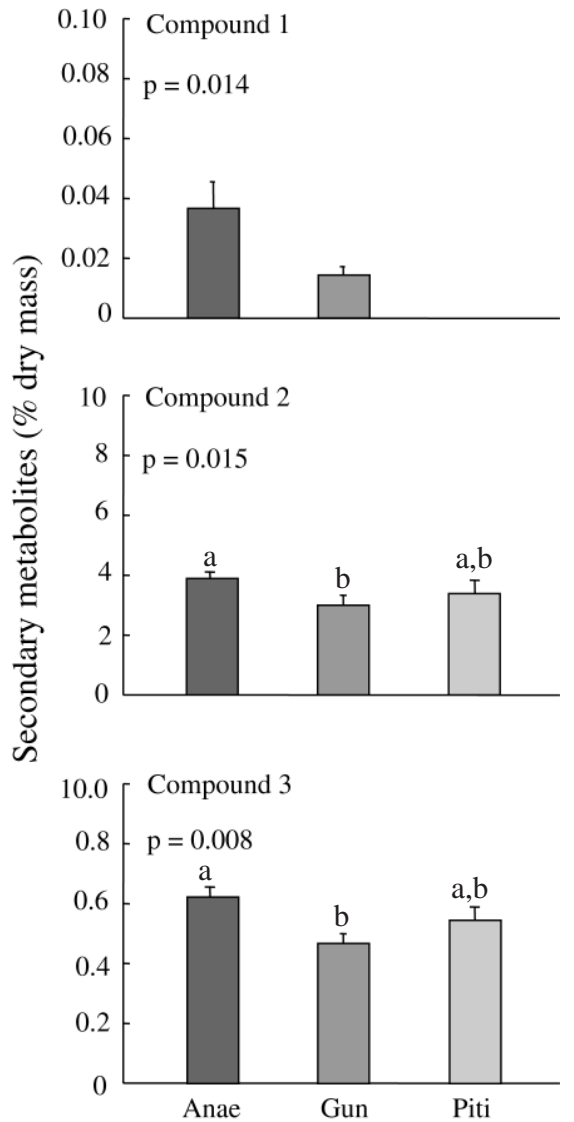

Fig. 4. Dysidea granulosa. Mean $( \pm 1$ SE) percent of compounds (as \% dry mass) of the 3 polybrominated diphenyl ethers in sponges from the 3 localities investigated. Note different scales of graphs. Further details as for Fig. 3

ing 10 specimens were placed under black plates (black treatment transplant; non-translucent regular Plexiglass plates painted black that blocked out both UV radiation and the visible light spectrum). All the plates used in this experiment were $3 \mathrm{~mm}$ thick, $30 \times$ $30 \mathrm{~cm}$ Plexiglass squares, with a hole drilled at each corner. Cable ties passed through these holes secured every plate to 4 rebar stakes that were driven into the substrate to form a square. At opposite corners, 2 stakes were then linked by another stake crossing at substrate level, which was used to secure the sponges underneath the center of the plates. The plates were 5 to $10 \mathrm{~cm}$ above the sponge. Light (photosynthetically active radiation, PAR) and ultraviolet radiation (UVR) were measured over $1 \mathrm{~d}$ in all the treatments at Cocos (Fig. 3) with an IL 1700 research radiometer (International Light) with a SUD 033 probe for PAR and a SUD 240 for UVR. We sampled a small $(1 \mathrm{~cm})$ piece of sponge from each replicate at the beginning of the experiment, after $3 \mathrm{wk}$, and at the end of the experiment ( $5 \mathrm{wk}$ ). We used a 2-way ANOVAR with Time as the within-subject factor and Treatment (Piti control,
Cocos transplant control, plate transplant control, UV treatment transplant, and black treatment transplant) as the between-subject factor.

Symbiont quantification. We quantified levels of chl a in tissues from Dysidea granulosa as an estimation of the amount of photosynthetic cyanobacteria in the sponge. Chlorophyll quantification is one of the most useful chemical methods for determining the total quantity of photosynthetic organisms (Parsons et al. 1984). According to our histological observations, the cyanobacterium Oscillatoria spongeliae is the only source of chl $a$ in the sponge, and therefore, levels of chl a must be related to the amount of cyanobacteria in the sponge (and their physiological condition). Overnight, we extracted $100 \mathrm{mg}$ of sponge dry mass with $5 \mathrm{ml}$ of $90 \%$ acetone. We kept all samples in the dark during chlorophyll extraction. Chlorophyll quantification was done immediately after extraction and we quantified our samples following a random order. We transferred $2 \mathrm{ml}$ of the resulting extracted solution to a fluorometry cell. Quantification of chl a in the solutions was done by a Shimadzu 2100 UV-visible recording spectrophotometer measuring absorbance extinctions at wavelengths of $630,645,665$ and $750 \mathrm{~nm}$ and then following the spectrophotometric equations of Jeffrey \& Humphrey (1975). The amount obtained $\left(\mu \mathrm{g} \mathrm{ml} \mathrm{m}^{-1}\right.$ ) was then multiplied by 5 and divided by the amount (in $\mathrm{mg}$ ) of sponge extracted, to obtain the final concentration of chlorophyll per mass of sponge.

We also used standard techniques for ultrastructural observation and quantification of the symbionts (Reynolds 1963). Briefly, we fixed about 20 small (1 to $2 \mathrm{~mm}^{3}$ ) fragments from the ectosome and choanosome of several sponges in $2.5 \%$ glutaraldehyde in cacodylate buffer ( $\mathrm{pH} 7.2$ ) for $6 \mathrm{~h}$ at $4^{\circ} \mathrm{C}$. The sponge pieces were then postfixed with $\mathrm{OsO}_{4}(1 \%$ in the same buffer $)$ for $2 \mathrm{~h}$ at $4^{\circ} \mathrm{C}$, dehydrated in an acetone series, and embedded in Spurr epoxy resin at room temperature. Ultra-thin sections obtained with a Reichert ultracut microtome were stained with uranyl acetate and lead

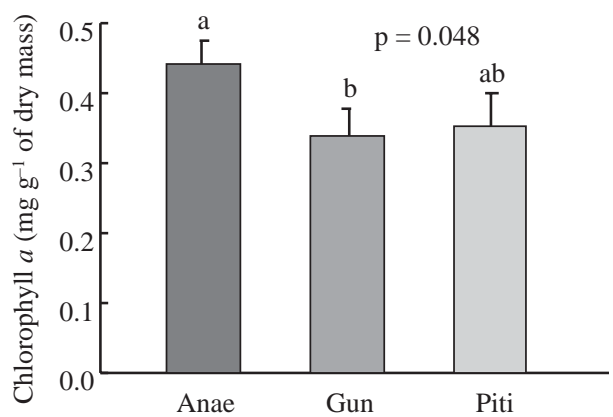

Fig. 5. Dysidea granulosa. Mean ( $\pm 1 \mathrm{SE}) \mathrm{chl}$ a content $\left(\mathrm{mg} \mathrm{g}^{-1}\right.$ sponge dry mass) in sponges from the 3 localities investigated. Further details as for Fig. 3 
citrate for ultrastructural observations in an Hitachi H800 MT microscope. We have made qualitative observations on various fragments from the ectosome and choanosome of multiple specimens, but a thorough quantification of symbionts across sponges and populations using ultrastructural techniques was beyond the scope of our study. To quantify symbionts in the ectosome and choanosome, we haphazardly took 5 pictures of the ectosome and choanosome of several sponge fragments. A 384-point grid over the pictures allowed calculation of percent bacteria and cyanobacteria in the sponge tissues as number of points over symbionts divided by total number of points.

\section{RESULTS}

\section{Variation at population level}

Significant differences in the concentration of secondary metabolites were found in sponges from all 3 localities investigated (ANOVA; Compound 1: $F=$ 7.331, $\mathrm{p}=0.014 ;$ Compound 2: $F=4.516 \mathrm{p}=0.015$; Compound 3: $F=5.230, \mathrm{p}=0.008$; Fig. 4). Sponges

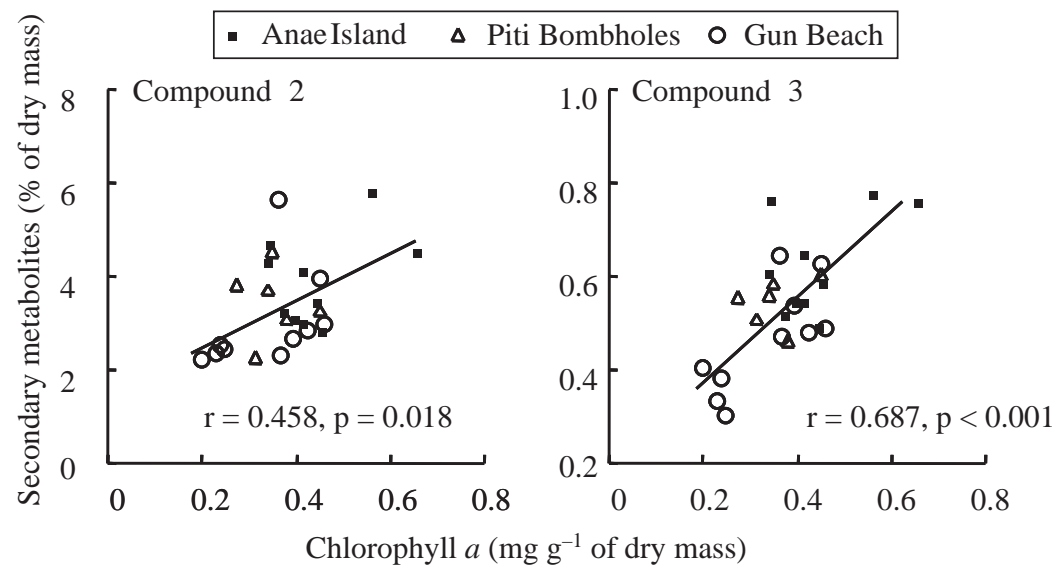

Fig. 6. Dysidea granulosa. Relationship between chl a content $\left(\mathrm{mg} \mathrm{g}^{-1}\right.$ sponge dry mass) and Compounds 2 and 3 (percent yield of sponge dry mass) in sponges from the 3 localities investigated. Note different scales of graphs
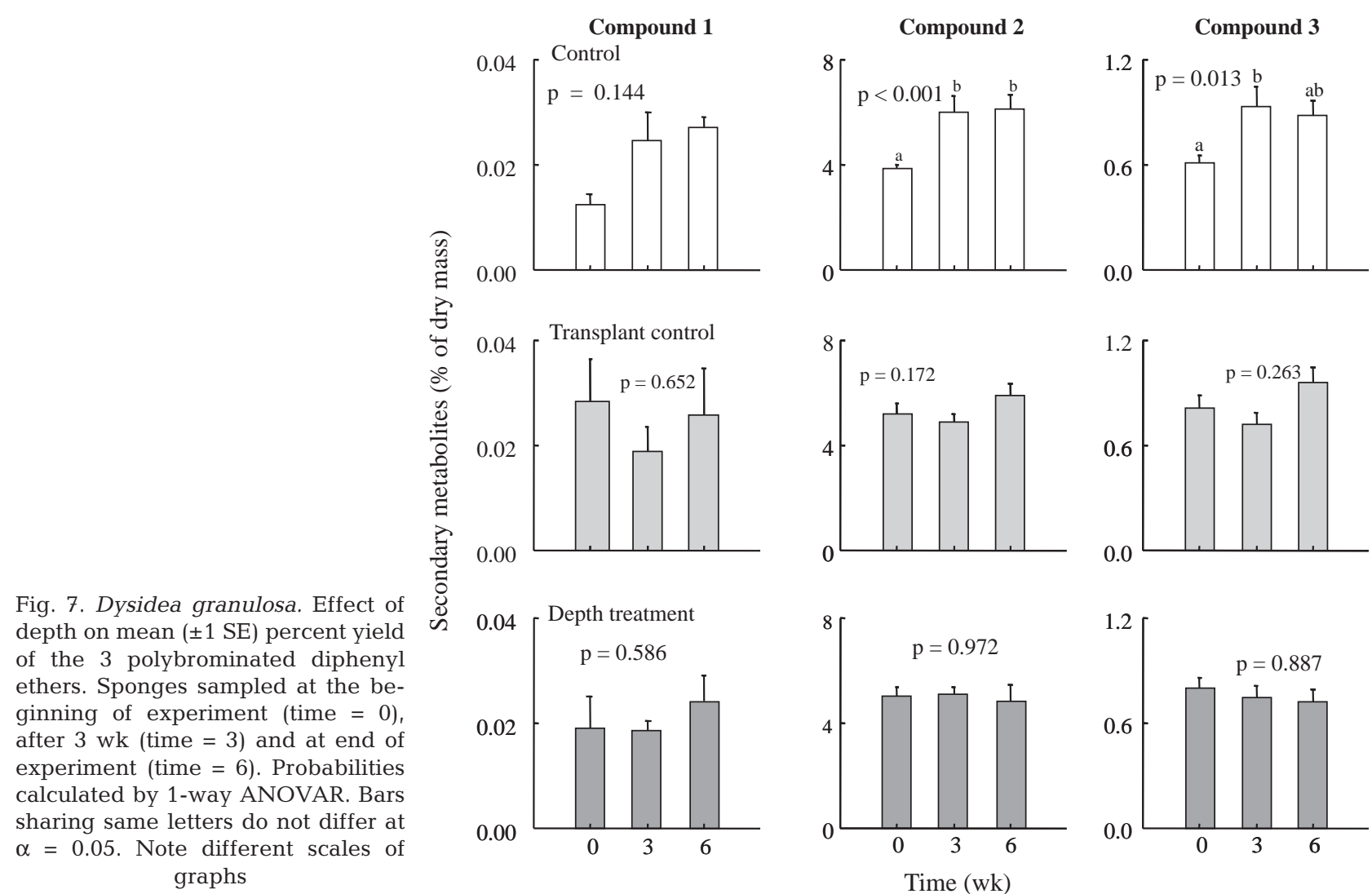

from Anae had significantly higher concentrations of the 3 secondary metabolites than sponges from Gun. Sponges from Piti had levels of Compounds 2 and 3 intermediate to those from Anae and Gun, while Compound 1 was absent or found at concentrations below our GC detection threshold (Fig. 4).

Levels of chl a had the same pattern as those of the secondary metabolites (ANOVA; $F=3.487, \mathrm{p}=0.048$ Fig. 5). In fact, we found a significant positive reladepth on mean $( \pm 1 \mathrm{SE})$ percent yield ginning of experiment (time $=0$ ) after $3 \mathrm{wk}$ (time $=3$ ) and at end of graphs
Fig. 7. Dysidea granulosa. Effect of sharing same letters do not differ at
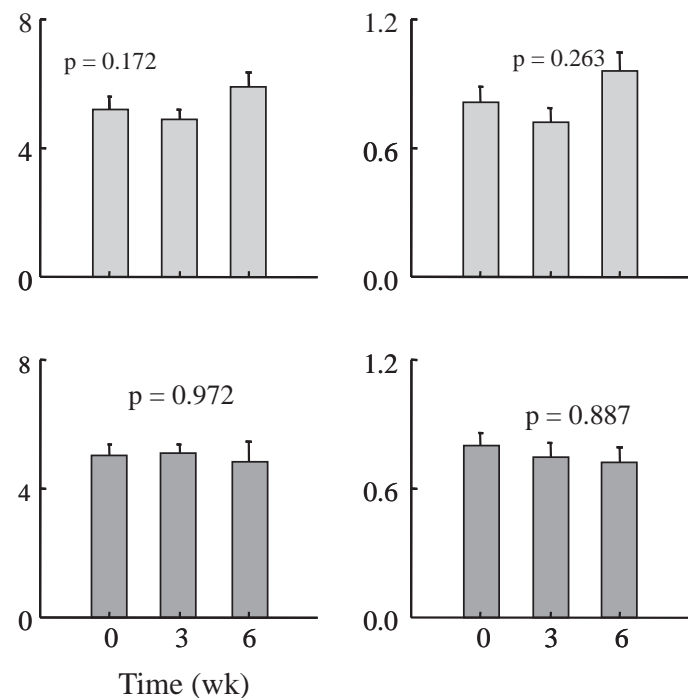


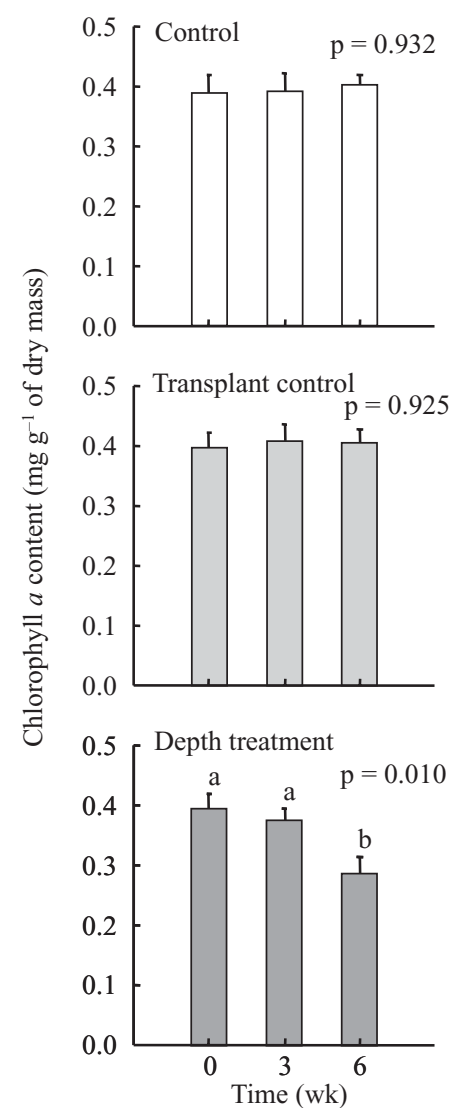

Fig. 8. Dysidea granulosa. Effect of depth on mean $( \pm 1 \mathrm{SE})$ chl a content ( $\mathrm{mg} \mathrm{g}^{-1}$ sponge dry mass. Further details as for Fig. 7

tionship between levels of chl a and concentrations of Compounds 2 and $3(\mathrm{r}=0.458, \mathrm{p}=0.018$ and $\mathrm{r}=$ 0.687, $\mathrm{p}<0.001$ respectively; Fig. 6).

\section{Depth, symbionts and secondary metabolites}

ANOVAR showed that levels of Compound 2, Compound 3 and chl a changed over time, depending on the treatment investigated (interaction terms: $F=$ 3.693, $\mathrm{p}=0.010 ; F=3.031, \mathrm{p}=0.026$; and $F=3.352, \mathrm{p}=$ 0.017 respectively). We were unable to perform this analysis with Compound 1 because of its absence from many sponges. A further analysis of the effect of time within each treatment level showed that levels of Compounds 2 and 3 increased over time in the control sponges $(F=11.721, \mathrm{p}<0.001$ and $F=5.605, \mathrm{p}=0.013$, respectively; Fig. 7), but remained stable in sponges from the transplant control (Compound 2: $F=1.665$, $p$ $=0.172 ;$ Compound 3: $F=1.470, \mathrm{p}=0.263$ ) and depth treatment (Compound 2: $F=0.028, \mathrm{p}=0.972$; Compound 3: $F=0.119, \mathrm{p}=0.887$ ). No differences over time were detected for Compound 1 (Fig. 7). Chl a content decreased over time in sponges from the depth treatment $(F=5.421, \mathrm{p}=0.010$; Fig. 8) while it remained stable in sponges from the control $(F=0.070, \mathrm{p}=0.932)$ and transplant control $(F=0.770, \mathrm{p}=0.925)$.

\section{Light, symbionts and secondary metabolites}

ANOVAR showed that levels of Compound 2 ( $F=$ 6.916, $\mathrm{p}=0.002)$, Compound $3(F=6.476, \mathrm{p}=0.003)$, and chl a $(F=4.631, \mathrm{p}=0.014)$ significantly decrease over time in the different light treatments (Figs. $9 \&$ 10). Also, treatment seemed to play a role in the levels of the major metabolite Compound $2(F=2.682, \mathrm{p}=$ 0.059). We were unable to perform this analysis with Compound 1 because of its absence from many sponges. A further analysis of the effect of time within each treatment level showed that levels of Compound 2 significantly decreased in sponges under the transparent plate (plate transplant control, $F=24.358, \mathrm{p}=$ 0.001 ) but not in the other treatments (Fig. 9). On the other hand, levels of chl a decreased in the control sponges (Cocos transplant control, $F=5.362, \mathrm{p}=0.046$ ) and in the black plate treatment (black treatment transplant, $F=11.343, \mathrm{p}=0.009$ ) but not in the other treatments (Fig. 10).

\section{Variation at sponge level}

We found significant variation in the levels of Compound 2 among sponges in the same habitat $(F=5.318$, $\mathrm{p}<0.001)$. We found no significant differences for Compound $3(F=2.124, \mathrm{p}=0.079)$ and there were insufficient data to analyze Compound 1. Levels of both Compounds 2 and 3 were similar among the different finger-like lobes or branches in individual sponges $(F=1.111, \mathrm{p}=0.397$ and $F=0.867, \mathrm{p}=0.608$ respectively).

In regard to differences between the outer and inner part of the sponge (ectosome and choanosome), all compounds investigated were more concentrated in the inner part of the sponge (Compound 1: $t=-2.483$, $\mathrm{p}=0.042$; Compound 2: $t=-2.180, \mathrm{p}=0.039$, Compound 3: $t=-3.195, \mathrm{p}=0.004$, Fig. 11). Chl a levels had an opposite pattern, with higher values in the ectosome than in the choanosome $(t=20.924$, $\mathrm{p}<0.001$, Fig. 12). Considering data from the ectosome and choanosome separately, there was a significant positive relationship between the concentrations of chl a and Compound 3 in both the ectosome and choanosome $(\mathrm{r}=0.516, \mathrm{p}=0.007$ and $\mathrm{r}=0.566, \mathrm{p}=0.003$ respectively Fig. 13), while Compound 2 was only related to chl $a$ in the ectosome $(r=0.478, p=0.013)$, and not in the choanosome $(p=0.248)$. 


\section{Symbiont quantification by ultrastructural observation}

Symbionts (pooled cyanobacteria and heterotrophic bacteria) were equally abundant in the outer and inner parts of the sponge (about $18 \%$ of the surface in our pictures were symbionts, $t=0.159, \mathrm{p}=0.878$; Fig. 14)
However, cyanobacteria and heterotrophic bacteria had opposite distributions in the sponge. The cyanobacterial population was basically restricted to the ectosome of the sponge $(t=25.468, \mathrm{p}<0.001$, Figs. 1 \& 14). Heterotrophic bacteria, on the other hand, are significantly more abundant in the choanosome $(t=$ -3.432, p = 0.009, Figs. 1 \& 14).
Compound 1

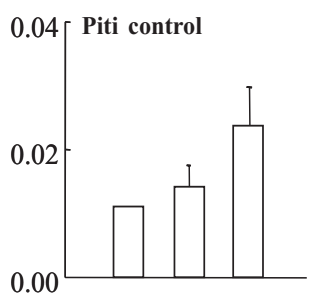

0.04 Cocos transplant control

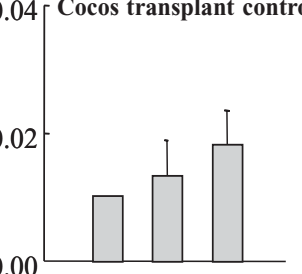

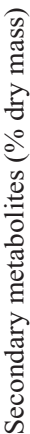
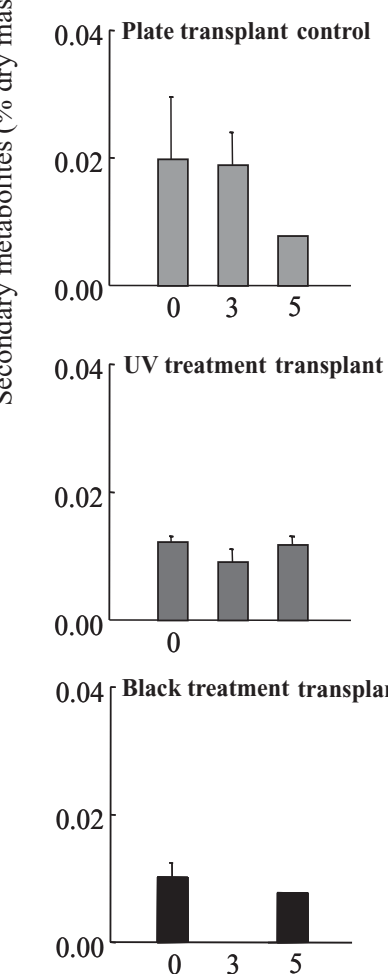

Compound 2
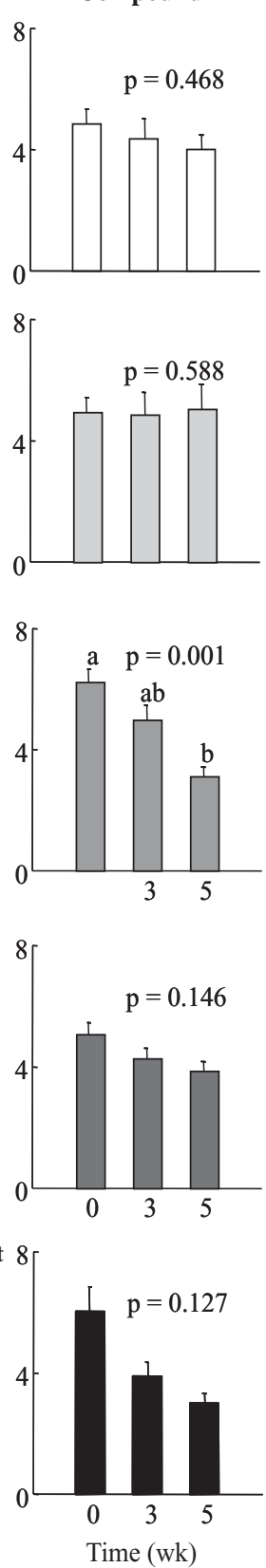

Compound 3
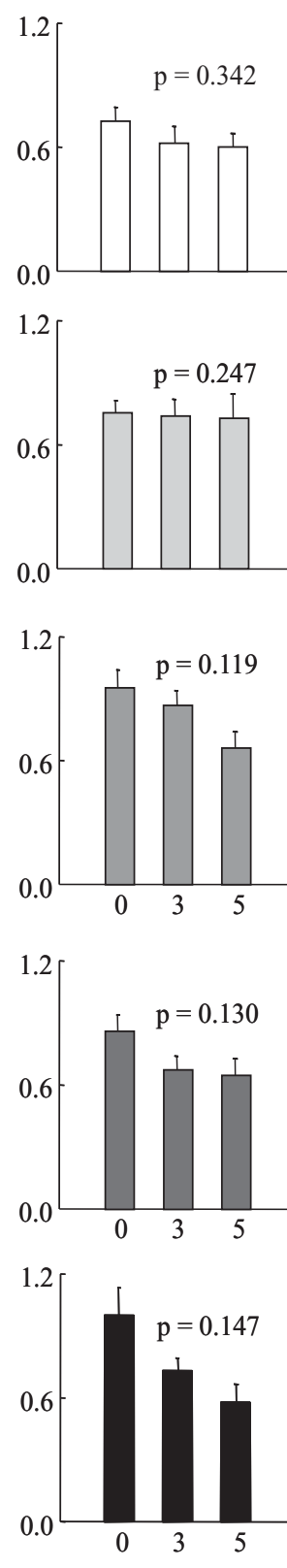

Fig. 9. Dysidea granulosa. Effect of light on mean $( \pm 1 \mathrm{SE})$ percent yield of the 3 polybrominated diphenyl ethers. Sponges sampled at beginning of experiment (Time $=0)$, after $3 \mathrm{wk}($ Time $=3$ ) and at end of experiment (Time =5). Note different scales of graphs. Further details as for Fig. 7

\section{DISCUSSION}

Irrespective of the scale investigated, the production of secondary metabolites is highly variable in marine organisms (Uriz et al. 1991, Steinberg 1992, Harvell et al. 1993, Becerro et al. 1995, 1998, de Nys et al. 1996). The causes and consequences of this variation are receiving much attention from marine researchers due to the important biological, ecological and evolutionary implications (Chanas et al. 1996, Cronin \& Hay 1996a,b, Hay 1996, Becerro et al. 1998, Sarà et al. 1998, Paul \& Puglisi 2004). Some marine organisms modify their levels of secondary metabolites according to the predation level (Paul \& Van Alstyne 1992, Teeyapant \& Proksch 1993, Cronin \& Hay 1996b); however, other factors that may influence this plasticity need investigation. Physical or environmental factors play a major role in determining levels of secondary chemical compounds in marine algae (Yates \& Peckol 1993, Cronin \& Hay 1996a), and may be equally important for invertebrates (Thompson et al. 1985, 1987, Becerro et al. 1995). Specimens of the sponge Aplysina fistularis collected from 5 to $15 \mathrm{~m}$ have high concentrations of aerothionin and homoaerothionin, while specimens collected above $5 \mathrm{~m}$ lack these compounds (Thompson et al. 1985). Photophilic specimens of the sponge Crambe crambe are less toxic than their sciaphilous counterparts (Becerro et al. 1995). In addition, many invertebrates host large quantities of symbionts in their bodies. Whether photosynthetic or heterotrophic, symbionts can be responsible for the production of secondary metabolites ascribed to the host (Unson \& Faulkner 1993, Oclarit et al. 1994, Unson et al. 1994, Bewley et al. 1996), and the symbiont population may be modulated by environmental factors such as the amount of light encountered by the host. 


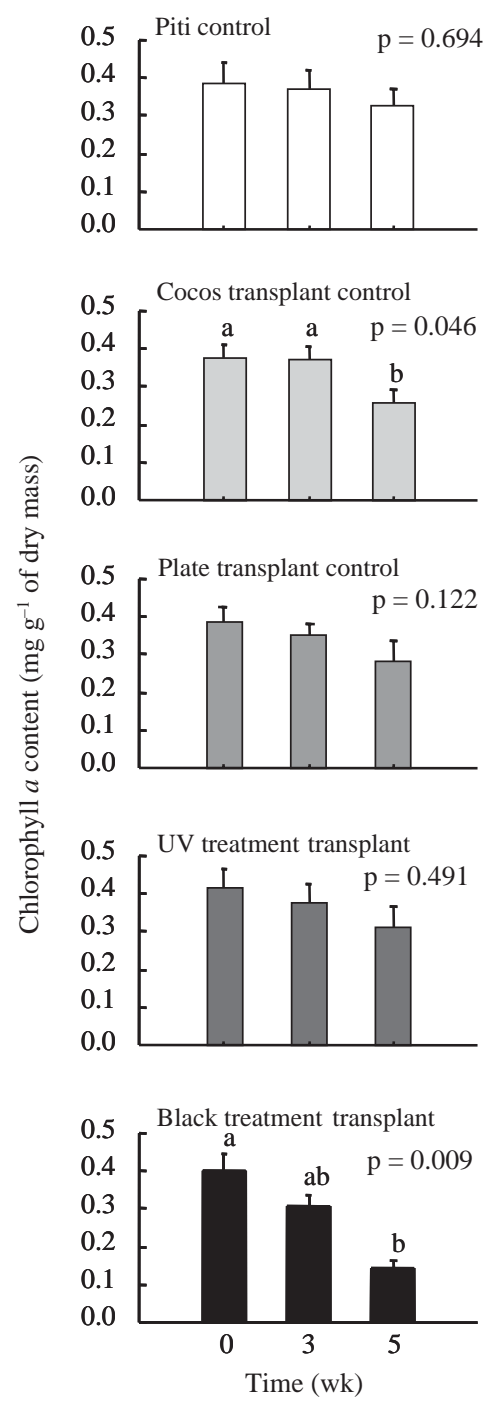

Fig. 10. Dysidea granulosa. Effect of light on mean $( \pm 1 \mathrm{SE})$ chl a content ( $\mathrm{mg} \mathrm{g}^{-1}$ sponge dry mass). Sponges sampled at beginning of experiment, after $3 \mathrm{wk}$ and at end of experiment. Probabilities calculated by 1-way ANOVAR. Further details as for Fig. 7

Dysidea spp. are widespread in shallow tropical waters and produce a great variety of compounds including many terpenes, sterols, alkaloids, amino acids and halogenated secondary metabolites (reviewed by Venkateswarlu et al. 1998). In their tissues many Dysidea spp. also have photosynthetic cyanobacteria and heterotrophic bacteria that seem capable of producing secondary compounds ascribed to the host. In the sponge $D$. herbacea, specific secondary metabolites are associated with different producers. Sponge cells produce sesquiterpenes (Unson \& Faulkner 1993, Flowers et al. 1998) while cyanobacteria produce polychlorinated compounds (Unson \& Faulkner 1993, Flowers et al. 1998). Also, specimens of $D$. herbacea can be subdivided into 2 chemotypes, some specimens produce sesquiterpenes and polychlorinated compounds and others produce only polybrominated diphenyl ethers (BDEs) (Faulkner et al. 1994). The species D. granulosa investigated in this study contained exclusively large quantities of BDEs as secondary metabolites, and the cyanobacterium Oscillatoria spongeliae and heterotrophic bacteria as symbionts. Although D. herbacea and D. granulosa are chemically and taxonomically closely related, they clearly differ externally and internally. D. herbacea is a thin sheet-like encrusting sponge with abundant cyanobacteria distributed throughout its tissues, while the thicker finger-like lobes of $D$. granulosa allow a clear differentiation between the cyanobacteriapacked ectosome and the bacteria-filled choanosome. In contrast to $D$. herbacea, both bacterial groups are abundant in D. granulosa.

There is contrasting information as to whether bacteria or cyanobacteria are the producers of BDEs. A bacterium of the genus Vibrio isolated from the Samoan sponge Dysidea sp. is capable of producing BDEs
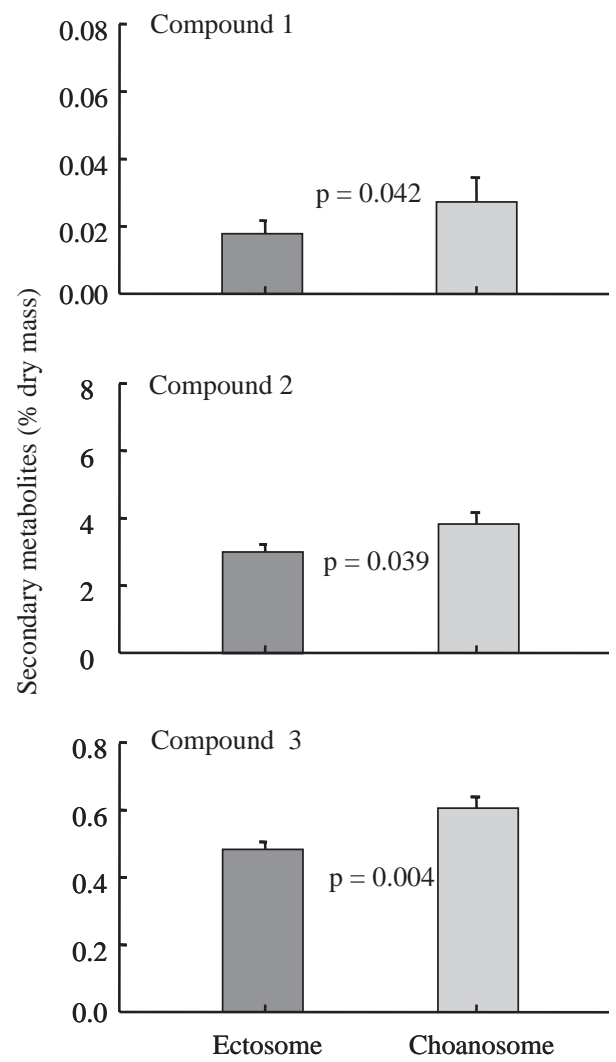

Fig. 11. Dysidea granulosa. Mean $( \pm 1 \mathrm{SE})$ percent yield of the 3 polybrominated diphenyl ethers in outer (ectosome) and inner (choanosome) part of sponge. Probabilities calculated by paired $t$-tests, 2 -tailed $\mathrm{p}$-values reported. Note different scales of graphs 
(Elyakov et al. 1991, Voinov et al. 1991), yet BDEs in D. herbacea were located in the photosynthetic cyanobacterium Oscillatoria spongeliae (Unson et al. 1994). Despite the contrasting evidence in the literature, it is widely accepted that cyanobacteria are responsible for the production of the BDEs, which are stored as crystals in the sponge mesohyl rather than in the cyanobacteria cells (Unson et al. 1994). Under the polarizing microscope, we examined fresh specimens of $D$. granulosa and, even though cyanobacteria and sponge cells and structures were easily observed, we failed to observe any evidence of crystals except for calcium carbonate crystals in the sand included in the fibers. There are 2 main arguments that refute the hypothesis of a bacterial origin of BDEs. First, lack of evidence of consistent association between the isolated Vibrio strain that produced polybrominated compounds and Dysidea species; and second, no evidence of the relative abundance of this bacterium in the sponge (Unson et al. 1994). Polybrominated compounds are typically present in Dysidea spp. at high concentrations, which would also require high concentrations of the symbiont responsible for their production (Unson \& Faulkner 1993, Faulkner et al. 2000). According to Unson et al. (1994), the high number of cyanobacteria could account for the high concentration of compounds found in $D$. herbacea; while according to Faulkner et al. (2000), the few eubacteria found in the sponge could not account for such high concentrations. In contrast, large numbers of bacteria were associated with the D. granulosa investigated in our study. Cyanobacteria are also abundant in D. granulosa, but are restricted to the outermost layer of the sponge. In view of the large number of bacteria in the tissues of $D$. granulosa, bacteria may account for the high concentration of secondary metabolites in this species. Whether the Dysidea sp. from Samoa investigated by

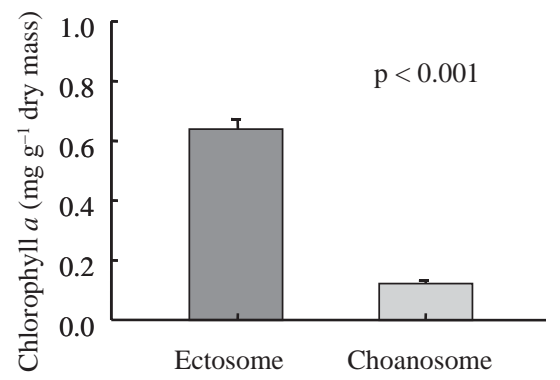

Fig. 12. Dysidea granulosa. Mean ( $\pm 1 \mathrm{SE}) \mathrm{chl}$ a content $\left(\mathrm{mg} \mathrm{g}^{-1}\right.$ sponge dry mass) in outer (ectosome) and inner (choanosome) part of sponge. Probabilities calculated by paired $t$-tests. 2-tailed p-values shown
Elyakov et al. (1991) and Voinov et al. (1991) and the D. granulosa investigated in our study are the same species is not known.

Alternatively, the rate of production and release of polybrominated compounds to the mesohyl may be more important than the actual number of producers. BDEs are reportedly stored in the sponge mesohyl, with only a relatively small amount found in the producers (Unson et al. 1994). If this is so, then fewer numbers of producers with a high rate of production might be compatible with high concentrations of BDEs in the sponge. The strongest proof of a metabolite being assigned to a specific producer could be obtained by isolating and culturing the organism and then demonstrate its metabolite production in culture (Faulkner et al. 2000). Pure cultures of the bacterium Vibrio sp. can

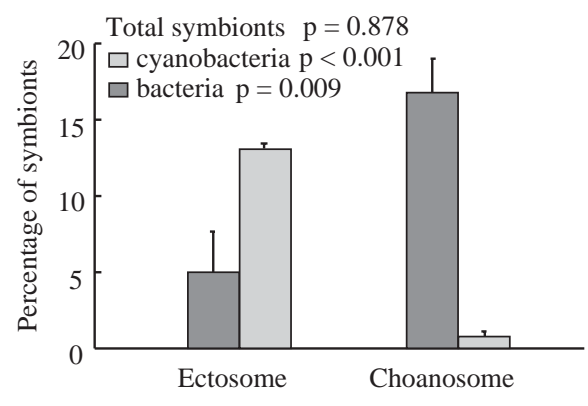

Fig. 14. Dysidea granulosa. Mean $( \pm 1$ SE) percent of symbionts (all photosynthetic cyanobacteria and heterotrophic bacteria), cyanobacteria and bacteria (calculated by TEM images) present in outer (ectosome) and inner (choanosome) part of sponge. Probabilities calculated by paired $t$-tests. 2-tailed p-values shown 
biosynthesize the polybrominated compound present in the sponge (Elyakov et al. 1991, Voinov et al. 1991) this has yet to be demonstrated for the cyanobacteria.

In our study, we found a positive relationship between secondary metabolites and chl a content in Dysidea granulosa, which seemed to indicate a positive relationship between cyanobacteria and production of BDEs (i.e. it may support the hypothesis that cyanobacteria are responsible for the production of polybrominated compounds in the sponge). However, within-colony analysis also showed that high levels of secondary metabolites are present in the choanosome, where chl a content is at its minimum, cyanobacteria are almost absent, and large numbers of bacteria share the mesohyl with the sponge cells. Our data may then indicate some sort of relationship between bacteria and secondary metabolites, supporting the hypothesis that bacteria and not cyanobacteria are responsible for the production of BDEs (Elyakov et al. 1991, Voinov et al. 1991). Our experimental evidence also demonstrated a lack of relationship between cyanobacteria and secondary metabolites. For example, when we tested the effect of depth, control sponges significantly increased their levels of Compounds 2 and 3 with increasing depth, while chl a content remained constant. Accordingly, we found no effects of depth and light on the production of secondary metabolites, suggesting that their production is not directly related to changes in the cyanobacterial population. Other factors may influence the concentration of secondary compounds. Although not to a statistically significant degree, the levels of secondary metabolites in sponges under any type of screen-plates tended to decrease over time (see Fig. 9). Plates could interfere with water flow and thus with nutrition, release of waste products, or the general health of the sponge, affecting not only the production of secondary metabolites but also many other traits of the sponge.

Our data suggest a negative relationship between cyanobacteria and bacteria at a within-colony level. Whether this relationship exists at the population level is not clear, but the absence of cyanobacterial polychlorinated compounds in the species with polybrominated compounds (Dunlop et al. 1982) might suggest some kind of negative interaction between symbionts. The BDEs in Dysidea spp. have antimicrobial properties (Faulkner et al. 1994) and might also have an effect on certain cyanobacterial strains. Dysidea spp. have genetically distinct cyanobacterial strains (Thacker \& Starnes 2003), so the possibility that cyanobacterial strains in Dysidea spp. differ in their capacity to produce or in their resistance to polybrominated and polychlorinated compounds cannot be ruled out. Flowers et al. (1998) found polychlorinated diketopiperazines in one preparation of Oscillatoria spongeliae but not in another from the same sponge. They suggested that the capability to synthesize secondary metabolites may depend on the physiological state of the symbiont or that there may be 2 closely related cyanobacterial strains within the sponge tissue. At the species level, there is little genetic variation in the cyanobacteria within D. herbacea (Thacker \& Starnes 2003), which would seem to indicate that the physiological state of the cyanobacteria was responsible for the contradictory results of Flowers et al. (1998). Alternatively, a cyanobacterial strain may fail to produce polychlorinated compounds under the influence of certain species of bacteria or sponge cells may play a role in regulating metabolite production in the symbionts. Cyanobacterial polychlorinated compounds are found in sponge specimens, whereby the sponge's own cells produce terpenes (Flowers et al. 1998). Whether or not terpenes play a role in regulating metabolite production in the symbionts is unknown. Genetically distinct cyanobacterial populations do occur in D. herbacea and D. granulosa (Thacker \& Starnes 2003), and this could partially explain the results of our study.

Symbiotic microbial populations have only recently received attention from marine chemical ecologists. Our data suggest that a world of interactions between symbionts and hosts remains largely uninvestigated. Taking microbial symbionts into account in studies of chemical ecology will not only expand our knowledge of the chemically mediated interactions that may regulate symbiotic populations, but also the role that symbionts and their secondary metabolites play in the biology, ecology and evolution of their hosts.

Acknowledgements. We thank D. Ginsburg, J. Starmer, R. Thacker and the marine technicians at the UOG Marine Laboratory for their diving assistance. M. Slattery helped with light measurements. G. Goetz, A. Himaya, C. Lacy, R. de Nys, W. Yoshida and the staff from UH Chemistry Department and Guam Crime Laboratory helped with compound isolation and quantification techniques. X. Turon and the University of Barcelona Technical Services helped with STEM. NIH Grants GM 388624 and 44796 to V.J.P. and a Basque Government Postdoctoral fellowship to M.A.B. provided funds for this research. This is contribution no. 561 from the University of Guam Marine Laboratory and contribution no. 584 of the Smithsonian Marine Station at Fort Pierce.

\section{LITERATURE CITED}

Bandaranayake WM, Bourne DJ, Sim RG (1997) Chemical composition during maturing and spawning of the sponge Dysidea herbacea (Porifera, Demospongiae). Comp Biochem Physiol B 118:851-859

Becerro MA, Turon X, Uriz MJ (1995) Natural variation of toxicity in the encrusting sponge Crambe crambe (Schmidt) in relation to size and environment. J Chem Ecol 21:1931-1946

Becerro MA, Paul VJ, Starmer J (1998) Intracolonial variation 
in chemical defenses of the sponge Cacospongia sp. and its consequences on generalist fish predators and the specialist nudibranch predator Glossodoris pallida. Mar Ecol Prog Ser 168:187-196

Bewley CA, Holland ND, Faulkner JD (1996) Two classes of metabolites from Theonella swinhoei are localized in distinct populations of bacterial symbionts. Experientia 52: 716-722

Cameron GM, Stapleton BL, Simonsen SM, Brecknell DJ, Garson MJ (2000) New sesquiterpene and brominated metabolites from the tropical marine sponge Dysidea sp. Tetrahedron 56:5247-5252

Carmeli S, Cojocaru M, Loya Y, Kashman Y (1988) Ten new rearranged spongian diterpenes from 2 Dysidea species. J Org Chem 53:4801-4807

Carte B, Faulkner DJ (1981) Polybrominated diphenyl ethers from Dysidea herbacea, Dysidea chlorea and Phyllospongia foliascens. Tetrahedron 37:2335-2339

Chanas B, Pawlik JR, Lindel T, Fenical W (1996) Chemical defense of the Caribbean sponge Agelas clathrodes (Schmidt). J Exp Mar Biol Ecol 208:185-196

Cimino G, Ghiselin MT (2001) Marine natural products chemistry as an evolutionary narrative. In: McClintock JB Baker BJ (eds) Marine chemical ecology. CRC Press, Boca Raton, FL, p 115-154

Coley PD, Barone JA (1996) Herbivory and plant defenses in tropical forests. Annu Rev Ecol Syst 27:305-335

Coll JC, Bowden BF, Clayton M (1990) Chemistry and coral reproduction. Chem Br 26:761-763

Cronin G, Hay ME (1996a) Within-plant variation in seaweed palatability and chemical defenses: optimal defense theory versus the growth-differentiation balance hypothesis. Oecologia 105:361-368

Cronin G, Hay ME (1996b) Induction of seaweed chemical defenses by amphipod grazing. Ecology 77:1531-1543

de Nys R, Steinberg PD, Rogers CN, Charlton TS, Duncan MW (1996) Quantitative variation of secondary metabolites in the sea hare Aplysia parvula and its host plant, Delisea pulchra. Mar Ecol Prog Ser 130:135-146

Dunlap WC, Schick JM (1998) Ultraviolet radiation-absorbing mycosporine-like amino acids in coral reef organisms: a biochemical and environmental perspective. J Phycol 34: 418-430

Dunlop RW, Kazlauskas R, March G, Murphy PT, Wells RJ (1982) New furano-sesquiterpenes from the sponge Dysidea herbacea. Aust J Chem 35:95-103

Elyakov GB, Kuznetsova T, Mikhailov VV, Maltsev II, Voinov VG, Fedoreyev SA (1991) Brominated diphenyl ether from a marine bacterium associated with the sponge Dysidea sp. Experientia 47:632-633

Faulkner DJ (2001) Marine natural products. Nat Prod Rep 18: $1-49$

Faulkner DJ, Unson MD, Bewley CA (1994) The chemistry of some sponges and their symbionts. Pure Appl Chem 66: 1983-1990

Faulkner DJ, Harper MK, Haygood MG, Salomon CE, Schmidt EW (2000) Symbiotic bacteria in sponges: sources of bioactive substances. In: Fusetani N (ed) Drugs from the sea. Karger, Basel, p 107-119

Flowers AE, Garson MJ, Webb RI, Dumdei EJ, Charan RD (1998) Cellular origin of chlorinated diketopiperazines in the dictyoceratid sponge Dysidea herbacea (Keller). Cell Tissue Res 292:597-607

Fu X, Schmitz FJ (1996) New brominated diphenyl ether from an unidentified species of Dysidea sponge - C-13 NMR data for some brominated diphenyl ethers. J Nat Prod (Lloydia) 59:1102-1103
Gleason DF (1993) Differential effects of ultraviolet radiation on green and brown morphs of the Caribbean coral Porites asteroides. Limnol Oceanogr 38:1452-1463

Harvell CD, Fenical W, Roussis V, Ruesink JL, Griggs CC, Greene CH (1993) Local and geographic variation in the defensive chemistry of a West Indian gorgonian coral (Briaerum asbestinum). Mar Ecol Prog Ser 93:165-173

Hay ME (1996) Marine chemical ecology: what's known and what's next? J Exp Mar Biol Ecol 200:103-134

Jeffrey SW, Humphrey GF (1975) New spectrophotometric equations for determining chlorophylls $a, b, c_{1}$ and $c_{2}$ in higher plants, algae and natural phytoplankton. Biochem Physiol Pflanz (BPP) 167:191-194

Karban R, Baldwin IT (1997) Induced responses to herbivory. University of Chicago Press, Chicago

Karentz D (2001) Chemical defenses of marine organisms against solar radiation exposure: UV-absorbing mycosporine-like amino acids and scytonemin. In: McClintock JB, Baker BJ (eds) Marine chemical ecology. CRC Press, Boca Raton, FL, p 481-520

Kelly M, Hooper J, Paul VJ, Paulay G, van Soest R, de Weerdt $R$ (2003) Taxonomic inventory of the sponges (Porifera) of the Mariana Islands. Micronesica 35-36:100-120

McClintock JB, Baker BJ (2001) Marine chemical ecology. CRC Press, Boca Raton, FL

Oclarit JM, Okada H, Ohta S, Kaminura K, Yamaoka Y, Iisuka T, Miyashiro S, Ikegami S (1994) Anti-bacillus substance in the marine sponge, Hyatella species, produced by an associated Vibrio species bacterium. Microbios 78:7-16

Parsons TR, Maita Y, Lalli CM (1984) A manual of chemical and biological methods for seawater analysis. Pergamon Press, Oxford

Paul VJ (1992) Ecological roles of marine secondary metabolites. Comstock Publishing Associates, Ithaca, NY

Paul VJ, Puglisi MP (2004) Chemical mediation of interactions among marine organisms. Nat Prod Rep 21:189-209

Paul VJ, Van Alstyne KL (1992) Herbivore-activated chemical defenses in the tropical green algae Halimeda spp. (Halimedaceae; Chlorophyta). J Exp Mar Biol Ecol 160: 191-203

Paul VJ, Cruz-Rivera E, Thacker RW (2001) Chemical mediation of macroalgal-herbivore interactions: ecological and evolutionary perspectives. In: McClintock JB, Baker BJ (eds) Marine chemical ecology. CRC Press, Boca Raton, FL, p 227-265

Reynolds ES (1963) The use of lead citrate at high pH as an electron opaque stain in electron microscopy. J Cell Biol $17: 208-212$

Rice EL (1984) Allelopathy. Academic Press, Orlando, FL

Rützler K (1990) Associations between Caribbean sponges and photosynthetic organisms. In: Rüztler K (ed) New perspectives in sponge biology. Smithsonian Institution Press, Washington, DC

Sarà M, Bavastrello G, Cattaneo-Vietti R, Cerrano C (1998) Endosymbiosis in sponges: relevance for epigenesis and evolution. Symbiosis 25:57-70

Sharma GM, Vig B, Burkholder PR (1969) Antimicrobial substances of marine sponges IV. In: Youngken HWJ (ed) Food-drugs from the sea. Proc Mar Technol Soc. Marine Technology Society, Washington, DC, p 307-310

Stapleton BL, Cameron GM, Garson MJ (2001) New chlorinated peptides from the tropical marine sponge Dysidea sp. Tetrahedron 57:4603-4607

Steinberg PD (1992) Geographical variation in the interaction between marine herbivores and brown algal secondary metabolites. In: Paul VJ (ed) Ecological roles of marine secondary metabolites. Comstock Publishing Associates, Ithaca, NY, p 51-92 
Stochaj WR, Dunlap WC, Shick JM (1994) Two new UVabsorbing mycosporine-like amino acids from the sea anemone Anthopleura elegantissima and the effects of zooxanthellae and spectral irradiance on chemical composition and content. Mar Biol 118:149-156

Tachibana K, Scheuer PJ, Tsukitani Y, Kikuchi H, Van Engen H, Clardy J, Gopichand Y, Schmitz FJ (1981) Okadaic acid, a cytotoxic polyether from two marine sponges of the genus Halichondria. J Am Chem Soc 103:2469-2471

Teeyapant R, Proksch P (1993) Biotransformation of brominated compounds in the marine sponge Verongia aerophoba-evidence for an induced chemical defense? Naturwissenschaften 80:369-370

Thacker RW, Starnes S (2003) Host specificity of the symbiotic cyanobacterium Oscillatoria spongeliae in marine sponges, Dysidea spp. Mar Biol 142:643-648

Thompson JE, Walker RP, Faulkner DJ (1985) Screening and bioassays for biologically active substances from forty marine species from San Diego, California, USA. Mar Biol 88:11-21

Thompson JE, Murphy PT, Bergquist PR, Evans EA (1987) Environmentally induced variation in diterpene composition of the marine sponge Rhopaloeides odorabile. Biochem Syst Ecol 15:595-606

Unson MD, Faulkner DJ (1993) Cyanobacterial symbiont biosynthesis of chlorinated metabolites from Dysidea herbacea (Porifera). Experientia 49:349-353

Editorial responsibility: Charles Birkeland (Contributing Editor), Honolulu, Hawaii, USA
Unson MD, Holland ND, Faulkner DJ (1994) A brominated metabolite by the cyanobacterial symbiont of a marine sponge and accumulation of the crystalline metabolite in the sponge tissue. Mar Biol 119:1-11

Uriz MJ, Martin D, Turon X, Ballesteros E, Hughes R, Acebal C (1991) An approach to the ecological significance of chemically mediated bioactivity in Mediterranean benthic communities. Mar Ecol Prog Ser 113:287-297

Venkateswarlu Y, Ramesh P, Reddy NS (1998) Chemical and biological aspects of the sponge genus Dysidea, a review. Nat Prod Sci 4:115-129

Voinov VG, Elkin YN, Kuznetsova TA, Maltsev II, Mikhailov VV, Sasunkevich VA (1991) Use of mass spectrometry for the detection and identification of bromine-containing diphenyl ethers. J Chromatogr 586:360-362

Wilkinson CR (1978) Microbial associations in sponges. II. Numerical analysis of sponge and water bacterial populations. Mar Biol 49:169-176

Wink M (1999) Functions of plant secondary metabolites and their exploitation in biotechnology. CRC Press, Boca Raton, FL

Yasumoto T, Seino N, Murakami Y, Murata M (1987) Toxins produced by benthic dinoflagellates. Biol Bull (Woods Hole) 172:128-131

Yates JL, Peckol P (1993) Effects of ambient availability and herbivory on polyphenolics in the seaweed Fucus vesiculosus. Ecology 74:1757-1766

Submitted: June 30, 1999; Accepted: April 9, 2004

Proofs received from author(s): September 20, 2004 